\title{
The responses of soil microbial community and enzyme activities of Phoebe zhennan cultivated under different soil moisture conditions to phosphorus addition
}

\author{
Olusanya Abiodun Olatunji ${ }^{(1-2)}$, \\ Kaiwen Pan ${ }^{(1)}$, \\ Akash Tariq ${ }^{(1-2)}$, \\ Lin Zhang ${ }^{(1)}$, \\ Xiaogang $\mathrm{Wu}^{(1)}$, \\ Xiaoming Sun ${ }^{(1)}$, \\ Hongyan Luo ${ }^{(3)}$, \\ Dagang Song ${ }^{(1-2)}$, \\ Ningning $\mathbf{L i}^{(3)}$
}

\begin{abstract}
The importance of conservation and ecological restoration of the rare and economically important tree Phoebe zhennan is increasingly recognized. To this purpose, phosphorus ( $P$ ) addition has been proposed to improve soil biological attributes and face the anticipated drought under climate change, though few studies have investigated its effect on the interaction between the soil microorganisms and plant host, as well as on ecosystem productivity. We investigated the effect of $P$ addition on soil chemical properties, microbial communities, and enzyme activities in a soil planted with $P$. zhennan under two levels of water treatments (optimum water and drought treatments). $P$ additions had no significant effect on microbial communities, dissolved organic nitrogen (DON), pH and soil moisture (SM), though the available P (aP) increased. Compared with no $P$ treatment, alkaline phosphate and $\beta$-fructofuranosidase activities increased with $P$ additions in the drought treatment. Drought decreased the total phospholipid-derived fatty acids (PLFAs), arbuscular mycorrhiza fungi (AMF), and fungi PLFAs compared to the well-watered. These findings indicated that $P$ additions does not ameliorate the impact of drought on soil microbial communities and enzyme activities, except alkaline phosphate and $\beta$-fructofuranosidase, and $\mathrm{P}$ may not be responsible for regulating biochemical processes essential for maintaining the fertility of soil planted with $P$. zhennan under drought conditions. It is hypothesized that the lack of effects of $P$ addition on the majority of the microbial properties could be due to the soil mechanism employed by $P$. zhennan to tolerate harsh conditions.
\end{abstract}

Keywords: Alkaline Phosphatase, Biomass, Drought, Enzymes, Microbial, Phoebe zhennan

\section{Introduction}

Phoebe zhennan S. Lee (Family: Lauraceae; common name: Golden Phoebe), also known as Nanmu, is a well-known and rare tree species valued for its high timber quality and medicinal values (Hu et al. 2015). P. zhennan is listed as a threatened species by the International Union for Conservation of Nature (IUCN), and it is protected nationwide in China (Gao et al. 2016a). In the past few years, there has been a decline in the acreage of $P$. zhennan (Cao et al. 2016). At the moment, cultivation of $P$. zhennan has gained attention for use in tree resource conservation and ecological restoration projects. A program focusing on the protection and development of rare and precious tree species resources is currently being undertaken in Sichuan province (Hu et al. 2015). However, the increased aridity due to climate change may have implications for $P$. zhennan, either direct or indirect. To face this problem, it is therefore necessary to develop improved soil management practices such as phosphorus $(P)$ application. Indeed, our previous study suggested that $P$ addition could improve drought tolerance of $P$. zhennan seedlings through physio-biochemical adjustments (Tariq et al. 2017), though the impact of $P$ on soil chemical properties, microbial communities, and enzyme activities has not been investigated yet. Moreover, $\mathrm{P}$ in soil is subject to extensive physicochemical and biological reactions, with only a small component of total soil $\mathrm{P}$ being in a form directly available for plant or microbial uptake (Gao et al. 2016b). The seedling stage in forest restoration is critical for successful establishment. The application of $P$ might increase the tolerance of soil microbes to soil water deficit (Nielsen et al. 2015, Huang et al. 2016) and subsequently improve seedling performance after transplantation in the field.

Soil microorganisms are the critical link between the composition of above ground plant species and ecosystem functioning (You et al. 2014). Recent studies reported a close two-way interaction between microbial communities and plant host as a vital determinant of plant health and productivity (Sardans \& Penuelas 2012, Rivest et al. 2015, Gunina et al. 2017). While plants can affect soil microbial communities via their biomass, nutrient demand and water use efficiency, plant development can be strongly influenced by soil microbial communities (Sayer et al. 2016). This reciprocal exchange and interactions between plants 
and soil microbial communities underpins forest soil health, ecosystem function, and the ecosystem resilience after disturbance, which is fundamental in response to global change (Sayer et al. 2016). Although sev eral studies have reported that the coupling between plant and soil microorganisms is vital for plant performance and maintenance of soil health (Wei et al. 2017), both plants and soil microorganisms can be affected by change in soil water content and nutrient availability, such as P (Sanaullah et al. 2011, Cavagnaro 2016, Sun et al. 2018). Moreover, the shifts in soil chemical properties and biological parameters can provide an initial indication of soil quality because of their sensitivity, rapid response to short-term disturbances, and capacity to integrate many environmental factors ( $\mathrm{R}$ chardson et al. 2011, Temesgen et al. 2016).

Changes in soil water content and nutrient availability can affect soil microbial communities directly by altering their activity, but also indirectly through their influence on aboveground tree species (Huang et al. 2016, Sayer et al. 2016, Olatunji et al. 2018). Several studies have reported that drought can reduce the water potential of the physical soil matrix, and worsen nutrient deficiency by reducing its acquisition, mobility, and accessibility in the soil for plants and soil biota (Cavagnaro 2016, Sun et al. 2018). Therefore, it is anticipated that improved practices such as $\mathrm{P}$ application could buffer soil conditions, halting and even reversing the adverse effects of $P$ de ficiency in soils and increasing the stresstolerating ability of soil microbes (Nielsen et al. 2015, Huang et al. 2016, Olatunji et al. 2018). The influence of $P$ on aboveground plant communities is well understood; however, much less is known about the impact of $P$ addition on belowground micro bial communities. For instance, a limited response of soil microbial biomass and some enzyme activities to $P$ application have been reported (Yang \& Zhu 2015, Gao et al. 2016a). Such feedback may be context-dependent and could vary depending on the influence of host plant species, soil water content, and other variables (Wei et al. 2017, Sun et al. 2018). To our knowledge, even though the necessity for conservation and ecological restorations of $P$. zhennan is well recognized, there is limited information about the effect of $P$ addition as an improved management practice and its interaction with soil water content on $P$. zhennan chemical properties, microbial communities, and enzyme activities. Hence, understanding the effects of $P$ addition on be lowground microbial communities associated with $P$. zhennan seedlings under various levels of water treatment may be beneficial to improve cultivation strategies and may also provide better insights into effec tive management practices to maintain soil health under varying climate conditions.

In this study, we conducted a $\mathrm{P}$ addition experiment with two levels of water treatment (optimum water addition and drought) in a soil planted with P. zhennan, and measured the response of soil chemical properties, microbial communities, and enzyme activities. Our aim was to determine if $P$ addition affects the soil chemical parameters, microbial community, and enzyme activities of soil planted with $P$. zhennan under changes in soil water content, as well as to ascertain if improved practices such as $\mathrm{P}$ application could buffer the soil environment against drought conditions.

\section{Materials and methods}

\section{Experimental design}

This study was conducted at the Center for Ecological Studies, Chinese Academy of Science, Sichuan Province, China (104 $4^{\circ} 04^{\prime}$ $\mathrm{E}, 30^{\circ} 37^{\prime} \mathrm{N}$ ). The study area has a mild subtropical monsoon climate with a mean annual temperature of $16.7^{\circ} \mathrm{C}$ and precipitation of $945.6 \mathrm{~mm}$. Soils used in this study were collected at $15 \mathrm{~cm}$ depth and thoroughly mixed. The chemical properties of the soil samples were $0.89 \mathrm{~g} \mathrm{~kg}^{-1}$ total phosphorus (TP), $27.6 \mathrm{mg} \mathrm{kg}^{-1}$ available phosphorus (aP), $1.9 \mathrm{~g} \mathrm{~kg}^{-1}$ total nitrogen (TN), $26.7 \mathrm{~g} \mathrm{~kg}^{-1}$ total carbon (TC), and $\mathrm{pH}$ of 7.3 .

A complete randomized experimental design was established consisting of two levels of water treatment (well-watered and drought) and two levels of $P$ application (with and without $P$ ). The $P$. zhennan seedlings used in this study were grown for approximately two years, after which healthy and uniform seedlings were transplanted into $30(10 \mathrm{~L})$ pots filled with approximately $4000 \mathrm{~g}$ of a homogenized soil sample. Then, the plants were grown for another two months to allow adequate acclimation to the new environment before treatments were applied.

After 2 months growth, 20 healthy plants were selected and subjected to five replicates of four treatments: water with P-addition (WP), water only (W), drought with P-addition (DP), and drought only (D), for 3 months. Phosphorus fertilizer was supplied as sodium dihydrogen phosphate $\left(\mathrm{NaH}_{2} \mathrm{PO}_{4}, 25.5 \% \mathrm{P}\right)$ at the rate of $129.3 \mathrm{mg} \mathrm{P}$ per pot. The fertilizer was mixed with 200 $\mathrm{ml}$ of water per pot and supplied every 30 days for three months.

The soil-relative water content (SRWC) was determined according to $\mathrm{Xu}$ et al. (2009) and categorized into two levels: optimum water addition (80\%-85\%) and severe drought (30\%-35\%). The SRWC of each pot was maintained by replacing the amount of water transpired and evaporated. A distance of $40 \mathrm{~cm}$ was maintained between pots to prevent shading by neighboring plants.

\section{Determination of soil parameters}

The soil obtained after removing plants from the pots was thoroughly homogenized and transferred to the laboratory in a sealed plastic bag. Soil moisture content was determined gravimetrically from mass loss after oven drying $10 \mathrm{~g}$ of moist soil to a constant weight at $105^{\circ} \mathrm{C}$ for $24 \mathrm{~h}$. The pH was measured using a pH meter (PHS- $25^{\circledR}$, INESA Instruments, China) at a ratio of 25 $\mathrm{ml}$ deionized water to $10 \mathrm{~g}$ soil. Ammonia $\left(\mathrm{NH}_{4}{ }^{+}-\mathrm{N}\right)$ and nitrate nitrogen $\left(\mathrm{NO}_{3}{ }^{-} \mathrm{N}\right)$ were extracted with $50 \mathrm{ml}$ of $2.0 \mathrm{M} \mathrm{KCl}$ and determined on a flow injection auto-analyzer (AutoAnalyzer $3^{\circledast}$, Bran-Luebbe, Germany). The aP was extracted with $0.5 \mathrm{M}$ $\mathrm{NaHCO}_{3}(\mathrm{pH}$ 8.2) according to Olsen \& Sommers (1982) and measured colorimetrically by the molybdate-ascorbic acid method (Murphy \& Riley 1962). Dissolved organic carbon (DOC) and nitrogen (DON) were extracted from fresh moist soils with an addition of $2 \mathrm{M} \mathrm{KCl}$ at $20{ }^{\circ} \mathrm{C}$ and measured using a TOC/ TN analyzer (Multi N/C $2100(S)^{\circledR}$, Analytik Jena AG, Germany).

\section{Estimation of microbial communities}

Using phospholipid-derived fatty acids (PLFAs - Bossio \& Scow 1998), soil microbial communities were assessed. Microbial lipids were extracted from frozen soil samples corresponding to $8 \mathrm{~g}$ dry mass of soil, placed in $50 \mathrm{ml}$ centrifuge tubes, and then extracted with a mixture of chloroform $\left(\mathrm{CHCl}_{3}\right)$, methanol, and phosphate buffer (1:2:0.8). The fatty acids in the lower chloroform phase were saponified and transformed into fatty acid methyl esters using a strong acid methylation. PLFAs methyl esters were separated and identified using gas chromatography (model $6890 \mathrm{~N}^{\oplus}$, Agilent, USA) coupled with a flame ionization detector (model 19091B-102 ${ }^{\circledR}$, Agilent, USA) and an HP-5 capillary column. The concentration of each PLFAs was quantified according to the 19:0 internal standards (nonadecanoic acid methyl ester). The abundance of individual fatty acids in each sample was expressed as nmol per g dry soil. Individual fatty acids were used to indicate broad functional groups of microorganisms according to existing PLFAs biomarker data (Frostegard et al. 2011, Kaiser et al. 2010). Actinomycetes and fungi were expressed by the PLFAs 10me 18:0, 10me 17:0, 10me

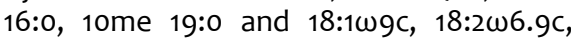
$16: 1 \omega 5 \mathrm{c}$, respectively. PLFAs $16: 1 \omega_{5} \mathrm{c}$ was used as the maker for arbuscular mycorrhiza fungi (AMF). The sum PLFAs i15:0, i16:0, a17:0, i14:0, a15:0, i17:0, i13:0, a16:0, i18:0 were chosen to represent the Grampositive $\left(\mathrm{G}^{+}\right)$bacteria, while Gram-negative $\left(\mathrm{G}^{-}\right)$bacteria were express by the sum of 16:1 $\omega 7 c, 15: 1 \omega 6 c, 16: 1 \omega 11 c, 18: 1 \omega 7 c$, cy17:0,

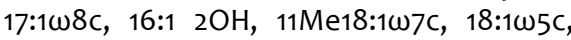
cy19:ow8c. The sum of all extracted PLFAs was used as the estimate of total microbial biomass (totPLFAs).

\section{Enzyme activities assay}

Activities of soil enzymes, including, $\beta$ glucosidase, alkaline phosphatase (AP), amidohydrolase (urease), and $\beta$-fructofuranosidase (invertase) were measured colorimetrically using the procedure of Tabatabai \& Bremner (1969), Tabatabai (1982), and Torres et al. (2016). Alkaline phos- 
phatase activities were determined by the release of p-nitrophenol (PNP) after cleavage of the enzyme-specific synthetic substrate. One gram of soil was incubated for 1 h at $37{ }^{\circ} \mathrm{C}$ with a mixture of $4 \mathrm{ml}$ modified universal buffer ( $\mathrm{pH}$ 6.5), $0.2 \mathrm{ml}$ toluene, and $1 \mathrm{ml}$ appropriate substrate solution. One $\mathrm{ml} 0.5 \mathrm{M} \mathrm{NaOH}$ and $4 \mathrm{ml} 0.5 \mathrm{M} \mathrm{CaCl}_{2}$ were used to stop the reaction and allow for color development. The soil solution was then filtered and analyzed colorimetrically at $660 \mathrm{~nm}$. $\beta$-glucosidase activity was measured by adding $2 \mathrm{ml}$ of MUB pH 6.0 and $0.5 \mathrm{ml}^{\circ} 0.025 \mathrm{~mol} \mathrm{l}^{-1} p$-nitrophenyl $\beta$ D-glucopyranoside to $1 \mathrm{~g}$ soil sample and determined colorimetrically at $400 \mathrm{~nm}$ after incubating the mixtures at $37^{\circ} \mathrm{C}$. A control test was performed for each sample and the control (without soil), with the substrate being added after the reactions were stopped. For the determination of $\beta$ fructofuranosidase activities, $2 \mathrm{~g}$ air-dried soil sample was extracted with $0.2 \mathrm{ml}$ toluene, $5 \mathrm{ml}$ phosphate buffer solution, and $5 \mathrm{ml} 10 \%$ sucrose solution. The mixture was incubated at $37{ }^{\circ} \mathrm{C}$ for $2 \mathrm{~h}$. The resultant mixture was treated with a $3 \mathrm{ml}$ of 3,5-dinitrosalicylic acid solution and determined colorimetrically at $508 \mathrm{~nm}$. The urease activities were determined by incubating $2 \mathrm{~g}$ soil samples with an aqueous urea solution at $37^{\circ} \mathrm{C}$ for $2 \mathrm{~h} . \mathrm{NH}_{4}{ }^{+}$released from the soil was extracted with $1 \mathrm{M} \mathrm{KCl}$ solution and measured by a modified indophenol-blue colorimetric reaction.

\section{Data analysis}

For all the data obtained, homogeneity of variance was tested and log-transformation was applied when necessary (applicable to soil enzyme activities). Data obtained for chemical properties, enzyme activities, and microbial communities were analyzed by analysis of variance (two wayANOVA) using SPSS $^{\circledast}$ ver. 18.0 (SPSS Inc., Chicago, IL, USA). The treatment means were compared using Duncan's multiple range tests at the 0.05 probability level. Figures were prepared using Origin pro ver. 8.5 (OriginLab Corp., Northampton, MS, USA).

\section{Results}

\section{Effects of $P$ addition and water deficit} on soil chemical properties

$P$ addition had no significant effects on soil $\mathrm{NH}_{4}{ }^{+} \mathrm{N}, \mathrm{DON}, \mathrm{pH}$, and soil moisture contents (Tab. S1 in Supplementary material). Soil aP significantly increased $(p<$ 0.05 ) in soils receiving $P$ addition irrespective of the level of water treatments compared to those without $\mathrm{P}$ addition (Tab. 1). The aP of the drought treatments was higher (+P and -P: 105.33 and $48.66 \mathrm{mg} \mathrm{kg}^{-1}$ dry soil, respectively) than that of the wellwatered $(+P$ and $-P: 71.33$ and $44.66 \mathrm{mg}$ $\mathrm{kg}^{-1}$, respectively) treatments. $\mathrm{P}$ addition significantly increased $(p<0.05) \mathrm{NO}_{3}^{-} \mathrm{N}$ in well-watered treatments $\left(8.23 \mathrm{mg} \mathrm{kg}^{-1}\right)$ compared to no $\mathrm{P}\left(5.52 \mathrm{mg} \mathrm{kg}^{-1}\right)$, but no sig-

Tab. 1 - Effects of $P$ additions under the two level of water treatments on soil chemical properties. Values are means \pm SE. Means with different letters represent significant differences $(p<0.05)$ among the four treatments after Duncan's test. (SM): soil moisture (\%); $(\mathrm{pH})$ : soil $\mathrm{pH}$; (DOC): dissolved organic carbon; (DON): dissolved organic nitrogen; $\left(\mathrm{NH}_{4}^{+}-\mathrm{N}\right)$ : soil ammonium nitrogen $\left(\mathrm{mg} \mathrm{kg}^{-1}\right)$; $\left(\mathrm{NO}_{3}^{-}-\mathrm{N}\right)$ : soil nitrate nitrogen ( $\left.\mathrm{mg} \mathrm{kg}^{-1}\right)$; (aP): available phosphorus.

\begin{tabular}{lrrrr}
\hline \multirow{2}{*}{ Parameters } & \multicolumn{2}{c}{ Well-watered } & \multicolumn{2}{c}{ Drought } \\
\cline { 2 - 5 } & \multicolumn{1}{c}{$-\mathrm{P}$} & \multicolumn{1}{c}{$+\mathrm{P}$} & \multicolumn{1}{c}{$-\mathrm{P}$} & $+\mathrm{P}$ \\
\hline $\mathrm{NO}_{3}^{-}-\mathrm{N}\left(\mathrm{mg} \mathrm{kg}^{-1}\right)$ & $5.52 \pm 0.05^{\mathrm{c}}$ & $8.23 \pm 0.36^{\mathrm{b}}$ & $9.73 \pm 0.48^{\mathrm{a}}$ & $9.19 \pm 0.57^{\mathrm{a}}$ \\
\hline $\mathrm{NH}_{4}{ }^{\mathrm{N}}\left(\mathrm{mg} \mathrm{kg}^{-1}\right)$ & $0.16 \pm 0.04^{\mathrm{b}}$ & $0.17 \pm 0.01^{\mathrm{ab}}$ & $0.14 \pm 0.01^{\mathrm{b}}$ & $0.24 \pm 0.02^{\mathrm{a}}$ \\
\hline $\mathrm{DOC}\left(\mathrm{mg} \mathrm{kg}^{-1}\right)$ & $351.54 \pm 32^{\mathrm{a}}$ & $259.73 \pm 5.95^{\mathrm{b}}$ & $305.45 \pm 34^{\mathrm{a}}$ & $255.18 \pm 11.32^{\mathrm{b}}$ \\
\hline $\mathrm{DON}\left(\mathrm{mg} \mathrm{kg}^{-1}\right)$ & $103.29 \pm 1.38^{\mathrm{a}}$ & $117.83 \pm 6.84^{\mathrm{a}}$ & $114.27 \pm 7.73^{\mathrm{a}}$ & $128.85 \pm 13.18^{\mathrm{a}}$ \\
$\mathrm{aP}\left(\mathrm{mg} \mathrm{kg}^{-1}\right)$ & $44.66 \pm 3.30^{\mathrm{c}}$ & $71.33 \pm 0.66^{\mathrm{b}}$ & $48.66 \pm 3.52^{\mathrm{c}}$ & $105.33 \pm 3.33^{\mathrm{a}}$ \\
\hline $\mathrm{pH}$ & $7.52 \pm 0.09^{\mathrm{a}}$ & $7.71 \pm 0.11^{\mathrm{a}}$ & $7.50 \pm 0.08^{\mathrm{a}}$ & $7.58 \pm 0.03^{\mathrm{a}}$ \\
\hline $\mathrm{SM}$ & $15.51 \pm 0.86^{\mathrm{a}}$ & $16.28 \pm 0.70^{\mathrm{a}}$ & $9.21 \pm 0.41^{\mathrm{b}}$ & $9.05 \pm 0.56^{\mathrm{b}}$ \\
\hline
\end{tabular}

nificant differences were observed in $\mathrm{NO}_{3}^{-}$$\mathrm{N}$ between the $\mathrm{P}$ and no $\mathrm{P}$ additions in drought treatments. The DOC contents significantly decreased $(p<0.05)$ in soil receiving $P$ addition irrespective of the level of water treatments (Tab. 1). Generally, $\mathrm{NO}_{3}{ }^{-} \mathrm{N}, \mathrm{DON}$ and aP in drought treated soils was higher than those of the well-watered soil. The result of the ANOVA showed that the interactions of water and $P$ treatments had no significant effects on the majority of the soil chemical properties, except $\mathrm{NO}_{3}^{-}-\mathrm{N}$ and aP (Tab. S1 in Supplementary material).

Phosphorus addition and water deficit impacts on soil microbial community and enzyme activities

Soil microbial communities, including to- tal PLFAs, AMF, fungal PLFAs, $\mathrm{G}^{-}$bacteria, total bacteria, and actinomycete PLFAs in $\mathrm{P}$ addition treatments were not significantly different from the no $\mathrm{P}$ treatments in wellwatered or drought treated soils (Fig. 1, Fig. 2b, Fig. 2c). Compared with the no $P$ addition treatments, $\mathrm{P}$ addition significantly increased $(p<0.05) \mathrm{G}^{+}$bacteria in wellwatered treatments (Fig. 2a).

A significant effect of water treatments was observed on total PLFAs, AMF, fungi, $\mathrm{G}^{+}$bacteria, and total bacteria PLFAs (Tab. S2). Drought decreased the total PLFAs, AMF, fungi, and total bacteria compared to well-watered treatments (Fig. 1a, Fig. 1b, Fig. 1c, Fig. 2b). There were no significant differences in $\mathrm{G}^{-}$bacteria and actinomycete PLFAs in the well-watered and drought treatments (Fig. 1d, Fig. 2c). The results of
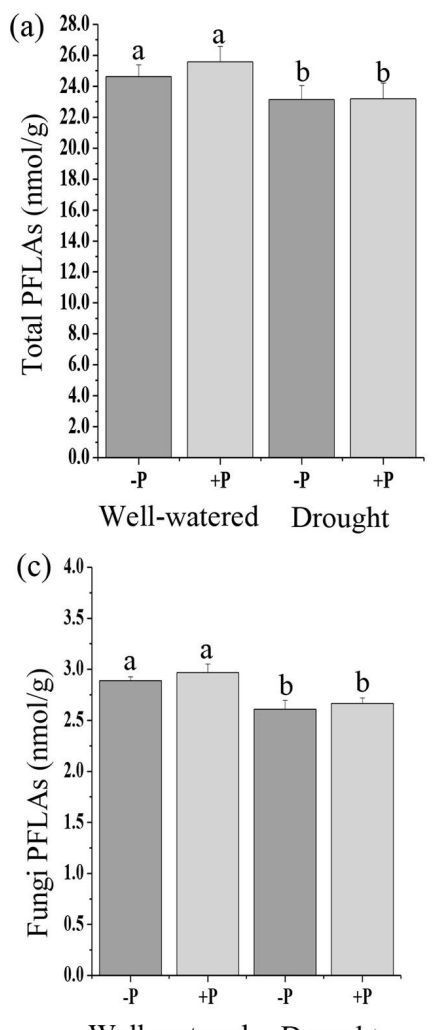

Well-watered Drought
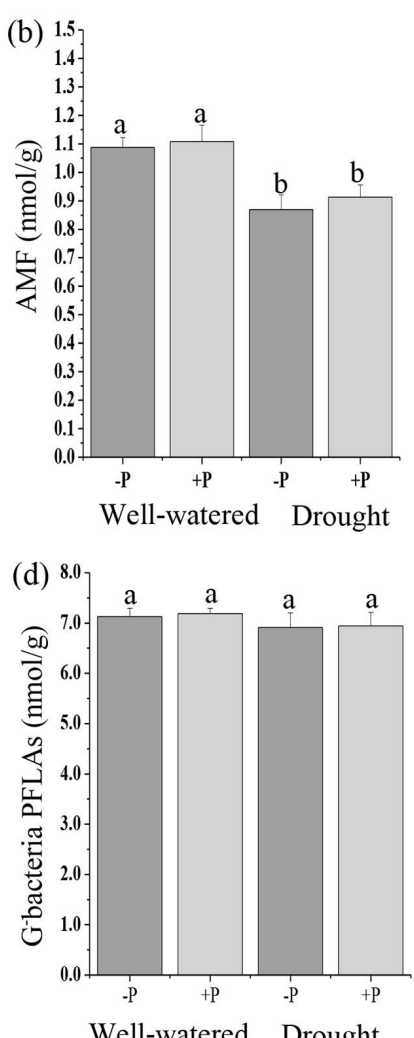

Fig. 1 - Response of soil microbial community, (a) total PLFAs, (b) AMF, (c) fungi PLFAs, (d) $\mathrm{G}$ bacterial PLFAs to phosphorus (P) application in well-watered and drought treatments. Different lowercase letters indicate significant differences $(p<0.05)$ among the treatments. The error bar represents standard error (SE). 

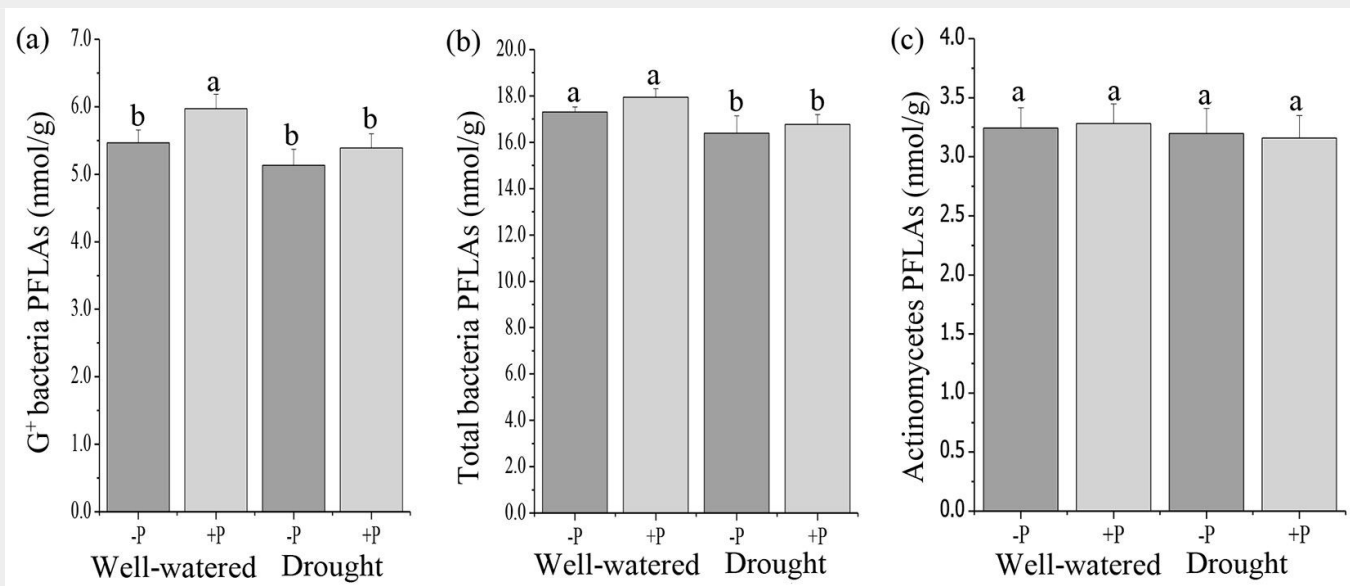

Fig. 2 - Response of soil microbial community, (a) $\mathrm{C}^{+}$bacterial PLFAs, (b) total bacterial PLFAs, and (c) actinomycetes PLFAs to phosphorus $(P)$ application in well-watered and drought treatments. Different lowercase letters indicate significant differences $(\mathrm{p}<0.05)$ among the treatments. The error bar represents standard error (SE).

the ANOVA indicated that there were no significant interactive effects of $\mathrm{P}$ addition and water treatments on all the microbial communities (Tab. S2 in Supplementary material).

The effects of $P$ addition on soil enzyme activities varied depending on the level of water treatments. $P$ addition significantly increased $(p<0.05)$ alkaline phosphate and $\beta$-fructofuranosidase activities in drought treatments but had no significant effects in well-watered treatments (Fig. 3a, Fig. 3b). $\beta$-glucosidase activity was lower with $\mathrm{P}$ addition, irrespective of the level of water treatments, although there were no significant differences compared to their no $\mathrm{P}$ counterparts (Fig. 3C).

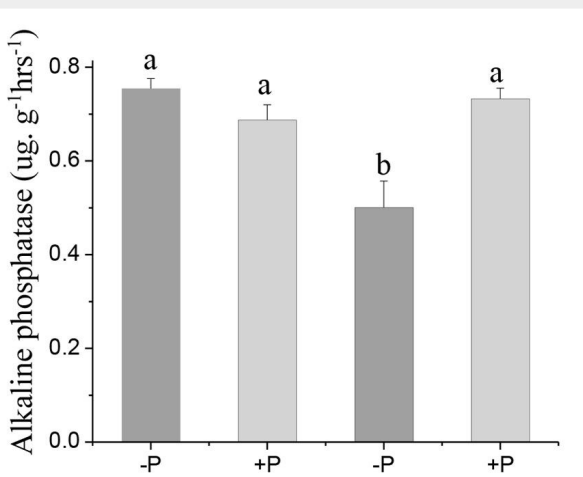

(a) Well-watered Drought

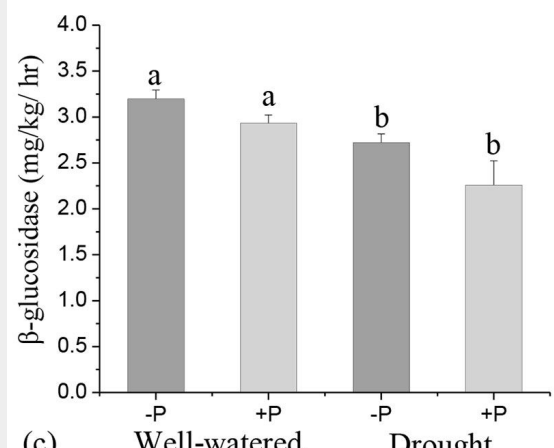

(c)

Well-watered Drought
The result of the ANOVA showed that $\mathrm{P}$ addition and its interactions with water treatment had no significant effects on any enzyme activity (Tab. S3 in Supplementary material). However, independent factors of water treatments alone significantly affected alkaline phosphate, $\beta$-glucosidase, and urease activities (Tab. S3). Urease and $\beta$-glucosidase activities were higher in wellwatered treatments than in the drought treatments (Fig. 3C, Fig. 3d).

\section{Discussion}

A comprehensive understanding of the interactive influence of climate and biotic factors on soil microbial communities and enzyme activities is vital for our under-
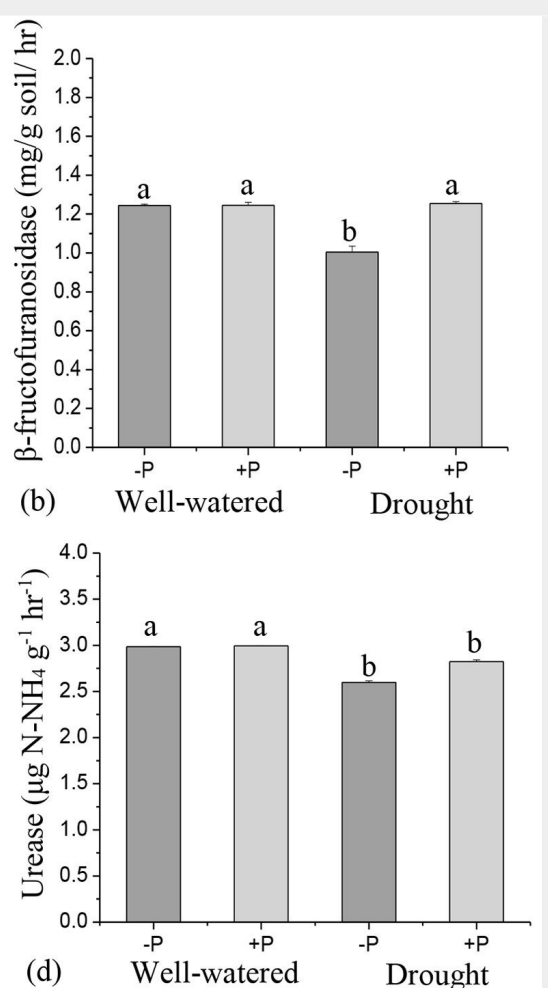

Fig. 3 - Response of soil enzyme activities, (a) alkaline phosphate, (b) $\beta$-fructofura nosidase, (c) $\beta$-glucosidase and urease to phosphorus $(P)$ application in well-watered and drought treatments. Different lowercase letters indicate significant differences $(p<0.05)$ among the treatments. The error bar represents standard error (SE). standing of changes in soil health (You et al. 2014), particularly as the aridity of the soil environment limits $P$ availability for plant growth in many soils (Richardson et al. 2011). In this study, we determined the effects of $P$ addition on soil chemical properties, microbial communities, and enzyme activities in soil planted with $P$. zhennan at two levels of water treatments. Consistent with previous studies (Sanaullah et al. 2011, Sayer et al. 2016), it was observed that the majority of the microbial communities and enzymes activities were partitioned along the water levels. The decrease in the total PLFAs, AMF, fungi, and total bacteria in drought treatments compared to well-watered treatments indicated that microbial communities were under physiological or nutritional stress, most probably because of competition between plant and soil microrganisms for limited accessible nutrients under drought conditions (Huang et al. 2016, Cavagnaro 2016, Olatuni et al. 2018). Studies have shown that decreases in soil moisture also reduce $\mathrm{N}$ and/or $\mathrm{P}$ uptake by plants (Cramer et al. 2009, Sardans \& Penuelas 2012). Likewise, the higher $\mathrm{NO}_{3}{ }^{-} \mathrm{N}$ and $\mathrm{DON}$ in drought treatments compared to the well-watered treatments suggested a reduction in nutrient uptake by $P$. zhennan during drought conditions. The negative feedback of less water and lower nutrient uptake could negatively affect the production capacity and fitness of plants when drought persists or becomes more severe (Sanaullah et al. 2011, Cavagnaro 2016, Sayer et al. 2016). Nevertheless, the abundance of actinomycetes, a heterogeneous group of bacteria noted for their filamentous and branching growth pattern, which may confer resistance to desiccation, were similar for both well-watered and drought treatments. These results suggested that $P$. zhennan may adapt to drought conditions by enhanced hydraulic conductance of the root system (Tariq et al. 2017) and increased production of biochemical compounds, which in turn increases actinomycete abundance (Koyama et al. 2017).

Contrary to the hypothesis that improved management practices such as $\mathrm{P}$ applica- 
tion could buffer soil conditions and increase the drought-tolerating ability of soil microbes (Nielsen et al. 2015, Huang et al. 2016), we found that $P$ addition had no significant impact on the total PLFAs, AMF, fungi PLFAs, $G^{-}$bacteria, total bacteria, and actinomycete PLFAs of P. zhennan. Although the root biomass of $P$. zhennan was enhanced with $\mathrm{P}$ addition, as reported by Tariq et al. (2017), the DOC, which represents the labile soil carbon and acts as the energy source for soil microbes (Huang et al. 2016), decreased with $P$ addition. This may be the reason for our results, which showed no significant effects of $\mathrm{P}$ addition on microbial communities. Moreover, the leaf dry matter, which can be used as a proxy for the proportion of vascular tissue, cellulose, insoluble sugar, and leaf lignin, and thus an additional carbon source for microbial communities, was lower with $P$ addition (Pei et al. 2016, Tariq et al. 2017). Leaf nitrogen content is an indicator of plant growth and resource uptake, and it has been recognized that $\mathrm{N}$-rich leaves could lead to bacterial dominated soil microbial communities (Pei et al. 2016). Corresponding to the lower leaf nitrogen content reported by Tariq et al. (2017) in drought-treated soil regardless of $\mathrm{P}$ addition, we observed that bacterial communities were lower in drought-treated soil. This further suggests that the application of $P$ as an improved management strategy could buffer the soil environment of $P$. zhennan against drought conditions. Studies have reported substantial increases in phosphatase activity in the rhizosphere of plants experiencing depletion of soil organic P (Richardson et al. 2011). However, we observed that increased aP corresponded to an increase in alkaline phosphate in $\mathrm{P}$ treated dry soil. The mechanism underpinning this observation may be that even in the presence of high aP, $\mathrm{P}$ uptake by $\mathrm{P}$. zhennan was constrained, hence hampering the effective utilization of $P$ by $P$. zhennan under drought stress (Richardson et al. 2011, Sardans \& Penuelas 2012). Taken together, the observed differences in the microbial communities appears to be related more to other abiotic variables or the growing nature of $P$. zhennan rather than to the availability of $\mathrm{P}$ due to $\mathrm{P}$ addition. Moreover, $P$. zhennan is a slow-growing forest tree species with a low mineral absorption rate and a slow growth strategy (Chapin 1980). Examining the impact of $P$ addition on the drought tolerance of $P$. zhennan, Tariq et al. (2017) demonstrated that, although drought stress severely affected the growth and metabolism, the species employs a range of strategies to tolerate harsh conditions. The strategies include limited stomatal conductance and transpiration rate, increased antioxidative activities, and accumulation of osmoprotectors. Although $P$. zhennan exhibits some inherent strategy which allowed it to lower the critical $P$ requirement for growth and allowed its soil environment to operate at lower accessible levels of soil $\mathrm{P}$ (Richardson et al. 2011), we suggest that the negative impact of less water and lower nutrient uptake could impact on the production capacity and fitness of $P$. zhennan when drought persists or becomes more severe. Our ongoing work is investigating other management strategies that could maintain soil health for the economically important but threatened $P$. zhennan under adverse environmental conditions.

\section{Conclusions}

Our results indicates that $\mathrm{P}$ addition does not have an impact on the composition of soil microbial communities or enzyme activities, except alkaline phosphate and $\beta$ fructofuranosidase, which are sensitive indicators of soil quality. In this study, the composition of microbial communities tended to be more sensitive to the level of water treatment than to $\mathrm{P}$ addition. Drought decreased the soil total PLFAs, AMF, fungal PLFAs, and $\mathrm{G}^{+}$bacteria compared to well-watered treatments, irrespective of $P$ addition. These results suggest that as $\mathrm{P}$ application may not be able to sustain the microbial properties of soil planted with $P$. zhennan, the negative impact of less water and lower nutrient uptake could impact the production capacity and fitness of $P$. zhennan when drought persists. The present findings highlight the need to further investigate a wide range of management strategies to maintain soil health for the economically important but threatened $P$. zhennan under changes in environmental conditions.

\section{Acknowledgements}

This study was supported by National Key R\&D program of China (Grant no. 2016 YFC0502101 and 2017YFC0505000), the Ministry of Sciences and Technology of China (Grant no. 2015BAD07B050304) and the National Natural Science Foundation of China (Grant nos. 41301315, 31370632 and 31500517). OA Olatunji thankfully acknowledges Chinese Academic of Sciences and The Word Academic of Sciences (CASTWAS) for the Fellowship. The authors appreciated the assistance of $X$. Tan and D. Huang, during the collection and preparation of the materials for this study.

\section{Conflict of Interest}

The authors declare that they have no conflict of interest.

\section{References}

Bossio DA, Scow KM (1998). Impacts of carbon and flooding on soil microbial communities: phospholipid fatty acid profiles and substrate utilization patterns. Microbial Ecology 35: 265278. - doi: $10.1007 / 5002489900082$

Cao J, Shang H, Chen Z, Tian Y, Yu H (2016). Effects of elevated ozone on stoichiometry and nutrient pools of Phoebe bournei (Hemsl.) Yang and Phoebe zhennan S. Lee et F. N. Wei seedlings in Subtropical China. Forests 7 (4): 78. doi: $10.3390 / f 7040078$
Cavagnaro TR (2016). Soil moisture legacy effects: Impacts on soil nutrients, plants and mycorrhizal responsiveness. Soil Biology and Biochemistry 95: 173-179. - doi: 10.1016/j.soilbio.20 15.12.016

Chapin SF (1980). The mineral nutrition of wild plants. Annual Review in Ecology and Systematic 11: 233-260. - doi: 10.1146/annurev.es.11.110 180.001313

Cramer MD, Hawkins HJ, Verboom GA (2009). The importance of nutritional regulation of plant water flux. Oecologia 161: 15-24. - doi: 10.1007/s00442-009-1364-3

Frostegard A, Tunlid A, Baath E (2011). Use and misuse of PLFA measurements in soils. Soil Biology and Biochemistry 43: 1621-1625. - doi: 10.1016/j.soilbio.2010.11.021

Gao Y, Cooper DJ, Ma X (2016a). Phosphorus additions have no impact on plant biomass or soil nitrogen in an alpine meadow on the QinghaiTibetan Plateau, China. Applied Soil Ecology 106: 18-23. - doi: 10.1016/j.apsoil.2016.04.020

Gao J, Zhang W, Li J, Long H, He W, Li X (2016b). Amplified fragment length polymorphism analysis of the population structure and genetic diversity of Phoebe zhennan (Lauraceae), a native species to China. Biochemistry Systematic and Ecology 64: 149-155. - doi: 10.1016/j.bse.2015.11. 001

Gunina A, Smith AR, Godbold DL, Jones DL, Kuzyakov Y (2017). Response of soil microbial community to afforestation with pure and mixed species. Plant and Soil 412: 357-368. - doi: 10.1007/S11104-016-3073-0

Hu Y, Wang B, Hu T, Chen H, Li H, Zhang W, Zhong Y, Hu H (2015). Combined action of an antioxidant defence system and osmolytes on drought tolerance and post-drought recovery of Phoebe zhennan S. Lee saplings. Acta Physiologiae Plantarum 37 (4): 489. - doi: 10.1007| s11738-015-1831-x

Huang J, Hu B, Qi K, Chen W, Pang X, Bao W, Tian $G$ (2016). Effects of phosphorus addition on soil microbial biomass and community composition in a subalpine spruce plantation. European Journal of Soil Biology 72: 35-41. - doi: 10.1016/ j.ejsobi.2015.12.007

Kaiser C, Frank A, Wild B, Koranda M, Richter A (2010). Negligible contribution from roots to soil-borne phospholipid fatty acid fungal biomarkers 18: $2 \omega 6.9$ and 18: $1 \omega 9$. Soil Biology and Biochemistry 42: 1650-1652. - doi: 10.1016/j.soil bio.2010.05.019

Koyama A, Steinweg JM, Haddix ML, Dukes JS, Wallenstein MD (2017). Soil bacterial community responses to altered precipitation and temperature regimes in an old field grassland are mediated by plants. FEMS Microbiology Ecology 94 (1): 1. - doi: 10.1093/femsec/fix156 Murphy J, Riley JP (1962). A modified single solution method for the determination of phosphate in natural waters. Analytical Chimica Acta 27: 31-36. - doi: 10.1016/S0003-2670(00)88444-5 Olatunji OA, Luo H, Pan K, Tariq A, Sun X, Chen W, Wu X, Zhang L, Xiong Q, Li Z, Song D, Zhang A, Sun $F$ (2018). Influence of phosphorus application and water deficit on the soil microbiota of $\mathrm{N} 2$-fixing and non- $\mathrm{N}$-fixing tree. Ecosphere. doi: $10.1002 /$ ecs2.2276

Olsen SR, Sommers LE (1982). Phosphorus. In: "Methods of Soil Analysis, Part 2" (Page AL, 
Miller RH, Keeney DR eds). Agronomy Society of America and Soil Science Society of America, Madison, WI, USA, pp. 403-430.

Nielsen UN, Prior S, Delroy B, Walker JKM, Ellsworth DS, Powell JR (2015). Response of belowground communities to short-term phosphorus addition in a phosphorus-limited woodland. Plant and Soil 391: 321-331. - doi: 10.1007/ s11104-015-2432-6

Pei Z, Eichenberg D, Bruelheide $H$, Krober W, Kuhn P, Li Y, Oheimb G, Purschke O, Scholten T, Buscot F, Gutknecht JLM (2016). Soil and tree species traits both shape soil microbial communities during early growth of Chinese subtropical forests. Soil Biology and Biochemistry 96: 180-190. - doi: 10.1016/j.soilbio.2016.02.004

Richardson AE, Lynch JP, Ryan PR, Delhaize E, Smith FA, Smith SE, Harvey PR, Ryan $\mathrm{MH}$, Veneklaas EJ, Lambers $\mathrm{H}$, Oberson A, Culvenor RA, Simpson RJ (2011). Plant and microbial strategies to improve the phosphorus efficiency of agriculture. Plant and Soil 349: 121156. - doi: 10.1007/s11104-011-0950-4

Rivest D, Paquette A, Shipley B, Reich BP, Messier C (2015). Tree communities rapidly alter soil microbial resistance and resilience to drought. Functional Ecology 29: 570-578. - doi: 10.1111/1365-2435.12364

Sardans J, Penuelas J (2012). The role of plants in the effects of global change on nutrient availability and stoichiometry in the plant-soil system. Plant Physiology 160: 1741-1761. - doi: 10.1104/pp.112.208785

Sanaullah M, Blagodatskaya E, Chabbi A, Rumpel C, Kuzyakov Y (2011). Drought effects on microbial biomass and enzyme activities in the rhizosphere of grasses depend on plant community composition. Applied Soil Ecology 48: 38-44. doi: 10.1016/j.apsoil.2011.02.004

Sayer EJ, Oliver AE, Fridley JD, Askew AP, Mills
RTE, Grime JP (2016). Links between soil microbial communities and plant traits in a speciesrich grassland under long-term climate change. Ecology and Evolution 7: 855-862. - doi: 10.1002/ ece3.2700

Sun F, Pan K, Li Z, Wang S, Tariq A, Olatunji OA, Sun X, Zhang L, Shi W, Wu X (2018). Soybean supplementation increases the resilience of microbial and nematode communities in soil to extreme rainfall in an agroforestry system. Science of the Total Environment 626: 776-784. doi: 10.1016/j.scitotenv.2018.01.063

Tabatabai MA, Bremner JM (1969). Use of p-nitrophenyl phosphate for assay of soil phosphate activity. Soil Biology and Biochemistry 1: 301-307. - doi: 10.1016/0038-0717(69)90012-1

Tabatabai MA (1982). Soil enzymes. In: “Chemical and Microbiological Properties. Methods of Soil Analysis, Part 2 ( $2^{\text {nd }}$ edn)" (Page AL, Miller $\mathrm{RH}$, Keeney DR eds). American Society of Agronomy-Soil Science Society of America, Madison, WI, USA, pp. 903-947.

Tariq A, Pan K, Olatunji OA, Graciano C, Li Z, Sun $F$, Sun $X$, Song $D$, Chen $W$, Zhang $A$, Wu $X$, Zhang L, Mingrui D, Xiong Q, Liu C (2017). Phosphorous application improves drought tolerance of Phoebe zhennan. Frontiers in Plant Science 8: 745. - doi: 10.3389/fpls.2017.01561

Temesgen D, Gonzalo J, Turrion MB (2016). Effects of short-rotation Eucalyptus plantations on soil quality attributes in highly acidic soils of the central highlands of Ethiopia. Soil Use and Management 32: 210-219. - doi: 10.1111/sum.12 257

Torres IF, Garcia C, Ruiz-Navarro A, Hernandez T, Bastida $F$ (2016). The enzymatic and physiological response of the microbial community in semi arid soil to carbon compounds from plants. European Journal of Soil Science 67: 456-469. - doi: 10.1111/ejss.12356
Wei Z, Hu X, Li X, Zhang Y, Jiang L, Li J, Guan Z, Cai $Y$, Liao $X$ (2017). The rhizospheric microbial community structure and diversity of deciduous and evergreen forests in Taihu Lake area, China. PLoS ONE 12 (4): e0174411. - doi: 10.1371/ journal.pone.0174411

Xu ZZ, Zhou GS, Shimizu H (2009). Are plant growth and photosynthesis limited by predrought following rewatering in grass? Journal of Experimental Botany 60: 3737-3749. - doi: 10.1093/jxb/erp216

Yang K, Zhu J (2015). The effects of $N$ and $P$ additions on soil microbial properties in paired stands of temperate secondary forests and adjacent larch plantations in Northeast China. Soil Biology and Biochemistry 90: 80-86. - doi: 10.1016/j.soilbio.2015.08.002

You Y, Wang J, Huang X, Tang Z, Liu S, Sun JO (2014). Relating microbial community structure to functioning in forest soil organic carbon transformation and turnover. Ecology and Evolution 4 (5): 633-647. - doi: 10.1002/ece3.969

\section{Supplementary Material}

Tab. S1 - ANOVA results of the effects of phosphorus addition, water treatment, and their interaction on soil chemical properties.

Tab. S2 - ANOVA results of the effects of phosphorus addition, water treatment, and their interaction on soil microbial PLFAs.

Tab. S3 - ANOVA results of the effects of phosphorus addition, water treatment, and their interaction on the enzyme activities.

Link: Olatunji_2725@supplo01.pdf 